\author{
Yurii Bilous \\ PhD Student of the Department of Geography of Ukraine and Regional Studies \\ e-mail: bilous_jura@ukr.net, ORCID ID: https://orcid.org/0000-0001-8539-275X \\ Yuriy Fedkovych Chernivtsi National University, \\ Mykhailo Kotsiubynsky street 2, building 4, Chernivtsi, 58012, Ukraine
}

\title{
SOCIAL AND GEOGRAPHICAL FEATURES OF THE FORMATION OF THE INTELLECTUAL POTENTIAL OF CHERNIVTSI OBLAST
}

The article studies the peculiarities of the formation of intellectual potential of Chernivtsi oblast by analyzing its components, and also analyzes the participation of students in student competitions in subjects and in the competition-defense of research works of students of the Small Academy of Sciences of Ukraine, as well as their results. The analysis of gender peculiarities of students' participation in the researched competitions is carried out, and also the geographical factors influencing formation of intellectual potential are considered.

In 2019, there were 372 preschool educational institutions, 403 general secondary education institutions, 16 vocational education institutions and 16 higher education institutions in Chernivtsi oblast, which provided relevant educational services and formed the intellectual potential of the region. In Chernivtsi oblast in the 2019-2020 academic year, 1,814 students took part in the III stage of student academic competitions. The largest number of participants was observed at the academic competition in geography, Ukrainian language and literature, history and biology. In total, 845 participants took top places. The best results were shown by students of Chernivtsi, Storozhynets AH, Novoselytsia AH and students of Kelmentsi rayon. As for the all-Ukrainian competitiondefense of research works, in 2020378 students took part in the competition, of which 187 participants took top places. The best results, as in the academic competition, were demonstrated by students from Chernivtsi and Putyla rayon. Territorial differences in the development of intellectual potential occur under the influence of economic, demographic, legal, environmental, natural and other factors. The following indicators correlate most with the number of points scored by teams: the number of educational institutions in the rayon; share of new type of institutions (gymnasiums, lyceums, etc.); language of instruction.

The gender structure of participants and winners of these intellectual competitions deserves a special attention. Girls predominate in the gender structure of participants and winners of the academic competition and defense competition in most subjects, especially in subjects of the philological and philosophical cycle, while the number of boys predominates in the academic competitions of the physical and mathematical cycle. Thus, in Chernivtsi oblast there is a significant differentiation between territorial and administrative units according to the results of the III stage of student academic competitions in basic disciplines and the competition-defense of scientific works of students-members of the Small Academy of Sciences.

Key words: intellectual potential, education, general secondary education institution, student academic competition, competition-defense of scientific works.

\section{Юрій Білоус. СУСПЛЛЬО-ГЕОГРАФІЧНІ ОСОБЛИВОСТІ ФОРМУВАННЯ ІНТЕЛЕКТУАЛЬНОГО ПОТЕНЦАЛУ ЧЕРНІВЕЦЬКОЇ ОБЛАСТІ}

У статті розглянуто особливості формування інтелектуального потенціалу Чернівецької області шляхом аналізу його складових, а також було проведено аналіз участі учнів в учнівських олімпіадах з навчальних предметів та у конкурсі-захисті науково-дослідницьких робіт учнів-членів Малої академії наук України, а також їх результатів. Проведено аналіз гендерних особливостей участі учнів у досліджуваних конкурсах, а також розглянуто географічні чинники, що впливають на формування інтелектуального потенціалу.

У 2019 році в Чернівецькій області функціонувало 372 дошкільних навчальних закладів, 403 заклади загальної середньої освіти, 16 закладів професійної освіти та 16 закладів вищої освіти, які надавали відповідні освітні послуги та формували інтелектуальний потенціал регіону. Загалом у Чернівецькій області в олімпіадах взяли участь 1814 учнів, 3 яких призові місця здобули 845 учасників. Найкращі результати продемонстрували учні м. Чернівці, Сторожинецької об'єднаної територіальної громади (ОТГ), Новоселицької ОТГ та учні Кельменецького району. Що ж стосується Всеукраїнського конкурсу-захисту науково-дослідницьких робіт, то у 2020 році в конкурсі взяли участь 378 учнів, з яких 187 учасників здобули призові місця. Найкращі результати продемонстрували учні м. Чернівці та Путильського району.

Особливої уваги заслуговує гендерна структура учасників та призерів даних інтелектуальних змагань. В статевій структурі учасників та призерів олімпіади та конкурсу-захисті з більшості предметів переважають дівчата, особливо це проявляється у предметах філологічного та філософського циклу, натомість кількість хлопців переважає на олімпіадах фізикоматематичного циклу. Для кращого розуміння формування територіальних відмін у формуванні результативності учнів у інтелектуальних змаганнях нами було розглянуто чинники їх формування. Одним із найважливіших чинників $є$ кількість закладів загальної середньої освіти в громаді, що призводить до більшої конкуренції, а також типи навчальних закладів, що дозволяє зосередитись на вивченні окремих предметів.

Ключюві слова: інтелектуальний потенціал, освіта, заклад загальної середньої освіти, учнівські олімпіади, конкурсзахист наукових робіт.

Юрий БиЛоус. ОБЩЕСТВЕННО-ГЕОГРАФИЧЕСКИЕ ОСОБЕННОСТИ ФОРМИРОВАНИЯ ИНТЕЛЛЕКТУАЛЬНОГО ПОТЕНЦИАЛА ЧЕРНОВИЦКОЙ ОБЛАСТИ

В статье рассмотрены особенности формирования интеллектуального потенциала Черновицкой области путем анализа его составляющих, а также был проведен анализ участия учеников в олимпиадах по учебным предметам и в конкурсезащите научно-исследовательских работ учеников-членов Малой академии наук Украины, а также их результатов.

(C) Bilous Y., 2020 
Проведен анализ гендерных особенностей участия учеников в исследуемых конкурсах, а также рассмотрен ряд факторов, влияющих на формирование интеллектуального потенциала.

В 2019 году в Черновицкой области функционировало 372 дошкольных учебных заведений, 403 учреждения общего среднего образования, 16 учреждений профессионального образования и 16 учреждений высшего образования, которые предоставляли соответствующие образовательные услуги и формировали интеллектуальный потенциал региона. Всего в Черновицкой области в олимпиадах приняли участие 1814 учеников, из которых призовые места получили 845 участников. Лучшие результаты продемонстрировали учащиеся г. Черновцы, Сторожинецкой ОТГ, Новоселицкого ОТГ и ученики Кельменецкого района. Что же касается Всеукраинского конкурса-защиты научно-исследовательских работ, то в 2020 году в конкурсе приняли участие 378 учеников, из которых 187 участников получили призовые места. Лучшие результаты, как и в олимпиаде продемонстрировали ученики г. Черновцы, а также Путильского района.

Особого внимания заслуживает гендерная структура участников и призеров данных интеллектуальных соревнований. В половой структуре участников и призеров олимпиады и конкурса-защиты по большинству предметов преобладают девушки, особенно это проявляется в предметах филологического и философского цикла, зато количество ребят преобладает на олимпиадах физико-математического цикла. Для лучшего понимания формирования территориальных различий в формировании результативности учащихся в интеллектуальных соревнованиях нами были рассмотрены факторы их формирования. Одним из важнейших факторов является количество заведений общего среднего образования в обществе, что приводит к большей конкуренции, а также типы учебных заведений, позволяет сосредоточиться на изучении отдельных предметов.

Ключевые слова: интеллектуальный потенциал, образование, учреждение общего среднего образования, ученические олимпиады, конкурс-защита научных работ.

Formulation of the problem. Education is one of the determining factors in shaping the economic capacity of the state. The main criterion for assessing the level of development of education is the total intellectual potential of the region, the effective use of which contributes to strengthening the economic and political competitiveness of the state in the world and Europe. Sociogeographical studies of the intellectual potential of the region are designed to identify the factors of its formation, territorial differentiation of development and ways of implementation in the economy of the region and the state as a whole. Modern education reform in Ukraine will not only change the network of institutions that make up the educational space, but also redistribute the existing cumulative and specific intellectual potential of regions, which will have a significant impact on changes in various sectors of the economy and the state as a whole. For the first time, this will be reflected in the change in the territorial structure of those industries that focus on the scientific potential and entrepreneurial skills of employees.

An important stage in the study of the intellectual potential of the region is the assessment of student achievement in various intellectual competitions, including two, namely student school competitions in subjects and competition-defense of research papers of students of the Small Academy of Sciences of Ukraine, the results of which are taken into account at universities of Ukraine. These studies show the prospects for the development of a particular type of intellectual potential, the possibility of successful operation of relevant areas of training, specialties or educational programs in universities in the region, and accordingly the training of highly qualified specialists for the development of certain sectors. Therefore, the research topic is quite relevant, has a high practical value and its results can be used in developing strategies for forming a network of specialized institutions of general secondary education, training future employees in vocational and higher education institutions, as well as planning the development of certain industries that are oriented on scientific staff and scientific potential.

Analysis of recent research and publications. In modern domestic and foreign literature there are many scientific works devoted to the study of intellectual potential. It should be noted that most of the works of scientists study the intellectual potential as one of the components of economic development of the state or individual regions.

Such foreign economists as D. Ricardo, D. Bell, T. Schultz, G. Becker, K. Sweiby, M. Malone, A. Tofler, M. Fisher, T. Stewart and others devoted their works to the study of intellectual potential, namely such its components as education, science, intellectual capital. Among domestic economists, O. Grishnova, S. Zlupko, I. Revak, B. Leontiev, L. Semiv, T. Baulina, N. Ushenko, A. Gaponenko, S. Filippova, and K. Kovtunenko and others paid considerable attention to the comprehensive study of the concept of intellectual potential. The essence, content, formation, assessment of the intellectual potential are studied in the works of N. Verkhoglyadov, L. Dyba, T. Nosov, Y. Kanygin, I. Maksymenko, B. Titov, V. Petrenko, P. Pererva, L. Marchuk, Yu. Gava, M. Rosumnyi.

Socio-geographical studies of intellectual potential in Ukraine began in the last quarter of the twentieth century, and today there is insufficient study, as well as the actual lack of a single scientific and methodological view of this scientific concept, its selection, classification and importance in economic development. It is worth noting the works of such scientific geographers as: M. Palamarchuk, V. Nagirna, O. Shabliy, O. Topchiev, J. Oliynyk, T. Nych, O. Naumchuk and others. Their works consider a number of aspects of the formation and use of intellectual potential, as well as reveal the essence of the concept of "intellectual potential" as an object of socio-geographical research.

Setting objectives. The purpose of this study was a socio-geographical analysis of spatial differences in the intellectual potential of the region in the near future by studying the effectiveness of students in the allUkrainian student academic competitions and competition-defense of research papers of students of the Small Academy of Sciences of Ukraine. Based on the goal, we set the following tasks: to explore the essence of the concept of "intellectual potential"; to characterize the components of the intellectual potential of Chernivtsi oblast; to identify the spatial features of the formation of 
intellectual potential of Chernivtsi oblast; to analyze the territorial differences of students' participation in various intellectual competitions of the studied region.

Presentation of the main research material. In the modern scientific literature there are different definitions of the term "intellectual potential". Thus, Yu. Gava considers intellectual potential as a set of human, material and intangible potential [2], and B. Danylyshyn and V. Kutsenko consider intellectual potential as a purposeful active set of employees with the appropriate educational and qualification level, i.e. with their knowledge and skills [3]. N. Verkhohlyadova and O. Sidorov believe that intellectual potential is a part of intellectual resources that have the potential ability in the process of their formation and use to turn into intellectual capital [1]. T. Nych considers the intellectual potential as a system of intellectual resources with their knowledge, creative intellectual abilities and capabilities, infrastructural assets and intellectual property and market assets. According to her, it forms the intellectual capital of the region and its intellectual security. Depending on the territory, the following levels of intellectual potential formation are distinguished: national (state), regional, branch, local (settlement, enterprise or institution) [7].

According to O. Naumchuk, intellectual potential is a generalized characteristic of intellectual resources, according to place and time. Intellectual potential is greater than intellectual resources, because intellectual potential is the opportunities provided by intellectual resources at a certain time and in the future that can be used to achieve a certain goal. O. Naumchuk in the structure of the intellectual potential of the region identifies the following components: educational potential, scientific potential, innovation potential and cultural potential [5].

Three groups of factors contribute to the formation of the intellectual potential of the region: natural (creative abilities of individuals, public health, demographic situation in the country, the state of the environment); economic (state demographic policy, employment policy, state of labor resources, financing of science and education, the value of national income per capita, social protection system, pricing mechanism in the market of intellectual products, wage system); institutional (legislative regulation of intellectual activity, mechanism of protection of intellectual property) [5].

The basis of the development of intellectual potential is educational and scientific potential, because they are the basis of scientific and technological progress, without which it is impossible to imagine the successful development of the state.

The initial stage in the formation of intellectual potential is preschool education. In 2019, there were 372 pre-school institutions in Chernivtsi oblast, which is 9 institutions less than in 2017, when their number was the largest - 381 institutions. Most institutions operate in Chernivtsi - 59 and Storozhynets rayon - 39, and the least in Novodnistrovsk - 3. Preschools educated more than 31 thousand children, and the coverage of children in preschools was $62 \%$, which is the highest figure since 2000. In the region, there is a significant differentiation in the coverage of children with disabilities in urban $(88 \%)$ and rural $(47 \%)$ areas. An important aspect in the context of further formation of the intellectual potential of the region is the language of education of students. In $2019,89.3 \%$ of children with IPE were educated in the Ukrainian language, which is $4 \%$ less than in 2000. Education is also conducted in Romanian $10.7 \%$, and by 2015 also in Russian [17].

The next stage in the formation of the intellectual potential of the region is general secondary education. Since 2000, the number of ZSSO has been gradually decreasing from 462 institutions (which is the largest figure since independence) to 402 general secondary education institutions operating in Chernivtsi oblast as of September 1, 2019. Most institutions are concentrated in Chernivtsi and Storozhynets rayon (59 and 46 respectively). As for students, by 2015 there was a significant decrease in their number from 143 thousand in 1991 to 97.6 thousand in 2015, and since 2016 there has been a slight increase in their number to 105.5 thousand persons as of September 1, 2019 [17].

An important aspect of the study of the intellectual potential of the oblast region is the study of the level of knowledge of students. Determining the level of students' knowledge can be done through such intellectual competitions as the All-Ukrainian Olympiads in academic subjects and the All-Ukrainian competition-defense of research works of students of the Small Academy of Sciences of Ukraine.

All-Ukrainian student academic competitions in academic subjects are a kind of intellectual competitions in the educational space of Ukraine, designed to encourage young students to study certain subjects. Currently, competitions are held in 26 subjects (Ukrainian language and literature, foreign languages (English, Spanish, French, German), law, history, economics, mathematics, biology, geography, astronomy, physics, chemistry, ecology, computer science, information technology, labor education (technology), languages and literatures of national minorities (Russian, Polish, Hungarian, Romanian, Bulgarian, Moldavian, Modern Greek, Hebrew)) and take place in IV stages: I stage - school; II stage rayon (city); III stage - oblast; IV stage - All-Ukrainian [10].

In the 2019-2020 academic year, according to the Order of the Department of Education and Science of the Chernivtsi Oblast State Administration, competitions in Chernivtsi oblast were held in 20 subjects for students of grades 7-11 [12].

In Chernivtsi oblast in the 2019-2020 academic year, 1,814 students took part in the III stage of student competitions. The largest number of participants was observed in the academic competition in geography, Ukrainian language and literature, history and biology, the smallest - in the academic competition in Jewish language and literature, astronomy and economics (Fig. 1).

In total, in the 2019-2020 academic year, 845 students won prizes, of which: 91 - I place; 273 - II place; 481 - III place.

We determined the rating of the teams of Chernivtsi oblast based on the results of their performances at the III stage of student competitions in basic disciplines, based on the points scored. For each diploma received by a member of the team, the following number of points 
was awarded: I degree diploma -3 points; II degree diploma -2 points; III degree diploma -1 point.

The highest number of points according to the results of the III stage of student competitions was won by the team from Chernivtsi (553 points). Students of Storozhynets AH (69), Novoselytsia AH (63) and stu- dents of Kelmentsi region (49) won a fairly large number of points. The lowest number of points was obtained by students of Vikno AH, who did not take any top places, Stavchany AH, Seliatyn AH, Krasnoilsk AH and Voloka $\mathrm{AH}$, that received 1 point each (Fig. 2).

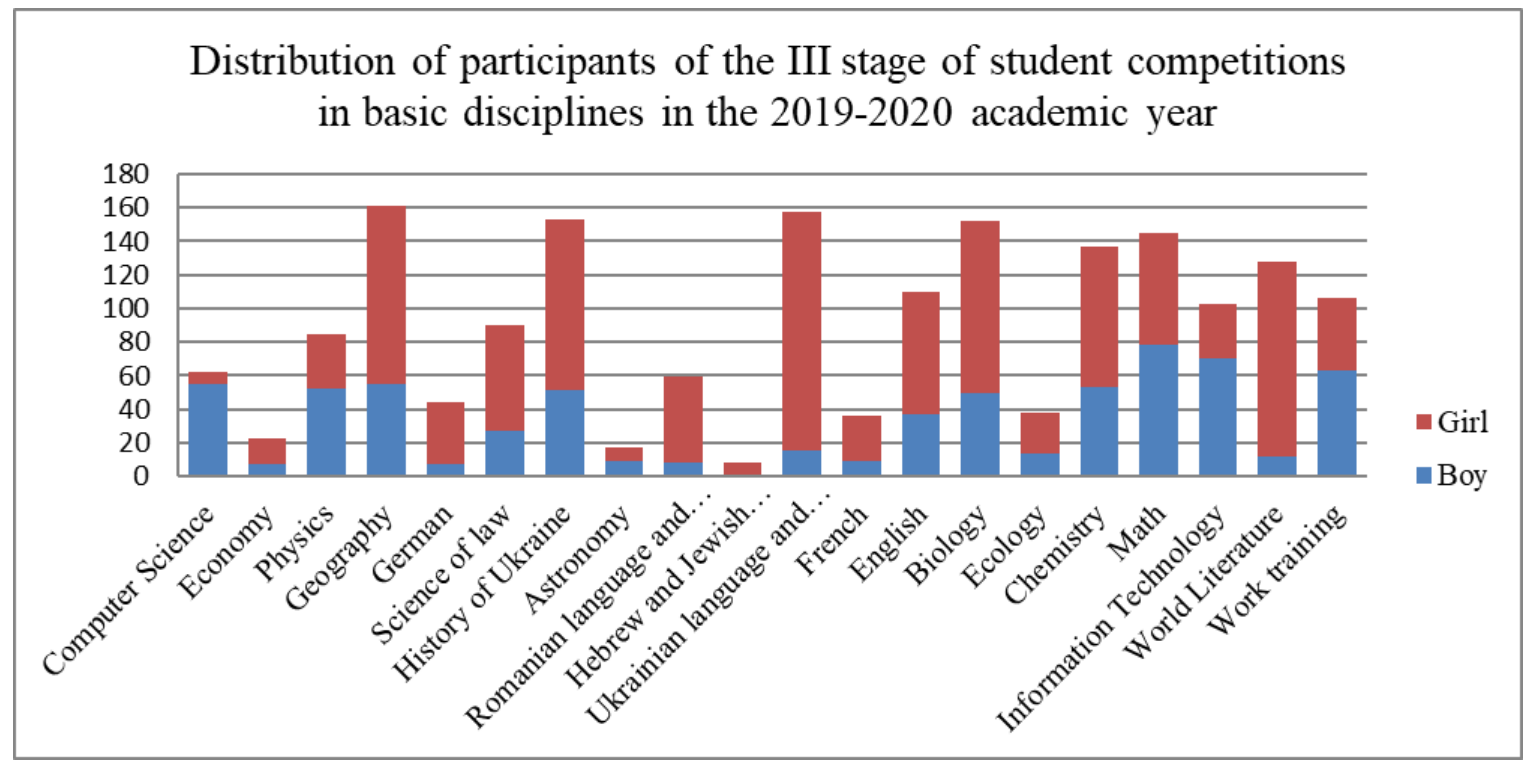

Fig. 1. Distribution of participants of the III stage of student competitions in basic disciplines in the 2019-2020 academic year

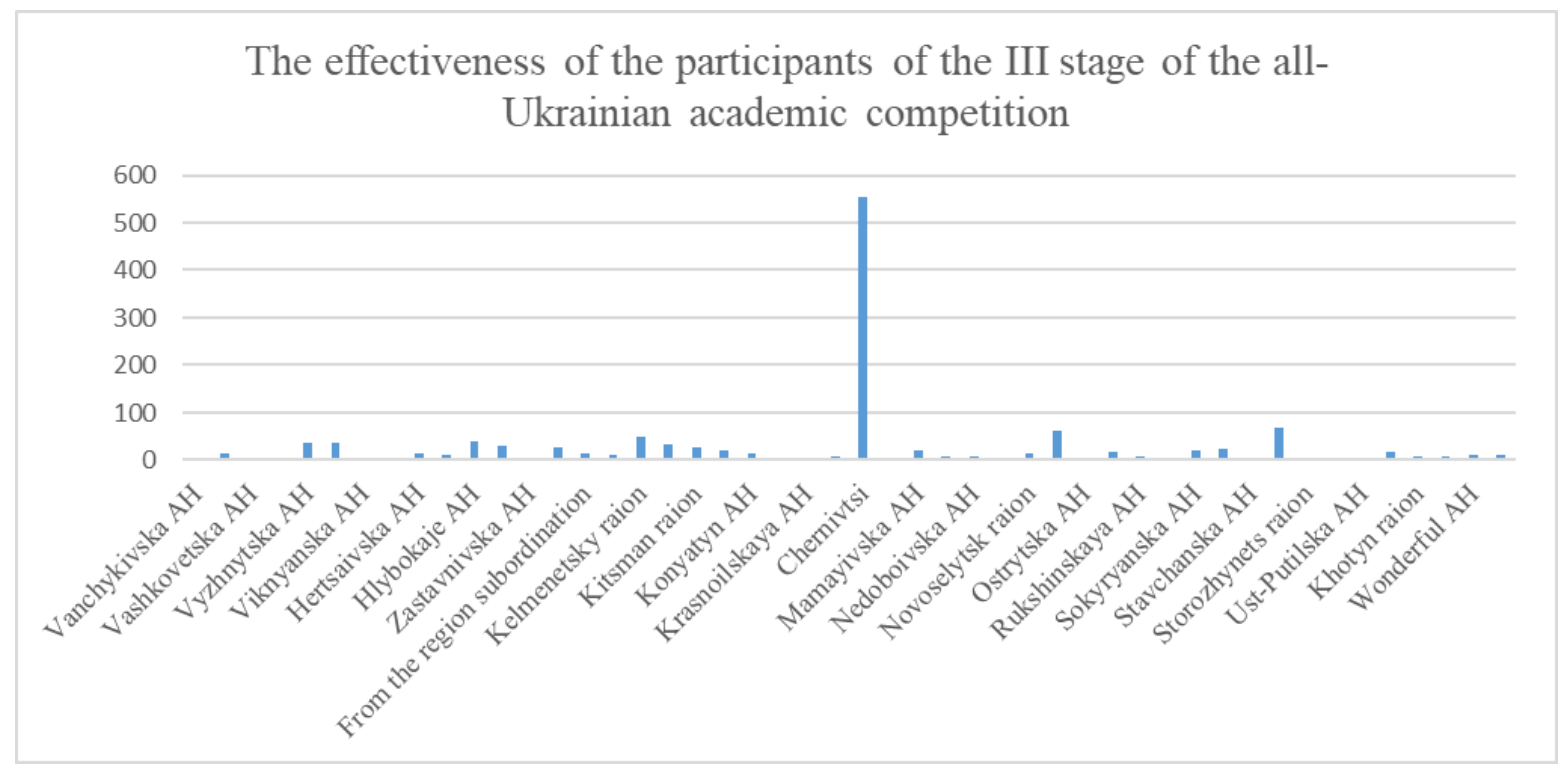

Fig. 2. The effectiveness of the participants of the III stage of the all-Ukrainian academic competition

The general rating of teams is quite interesting. This rating was calculated by the following formula: $\mathrm{R}_{\mathrm{gen}}=\frac{\sum \text { points }}{\mathrm{N} * \mathrm{Z}}$, where $\mathrm{N}-$ this is the total number of parallels in which student competitions in certain subjects were held, and is $71 ; \mathrm{Z}$ - this is the quantitative composition of teams for the III stage in each subject from each parallel.

According to the Order of the Department of Education and Science of the Chernivtsi Oblast State Administration, the number of team members in each subject and class is determined by the number of schools and students in the rayon, AH or city. For example, Chernivtsi in the III stage of student competitions can delegate 8 participants from each class, while the team of Kitsman $\mathrm{AH}-2$ participants, and Chahor $\mathrm{AH}$ - only 1 participant [12].

According to the general rating, the absolute leader is Chernivtsi (0.97). The teams of Novoselytsia $\mathrm{AH}$ (0.3), Hlyboka AH (0.28), Klishkivtsi AH (0.28), Mamayivtsi AH (0.28), Sokyryany AH (0.28) showed quite a high result.

As for educational institutions, the absolute leader 
of the rating is Chernivtsi Lyceum №1 of mathematical and economic specializations - 112 points. The second and third places were taken by Taras Shevchenko Chernivtsi Gymnasium №1 (56) and Chernivtsi Lyceum №3 of medical specialization (55), respectively. More than half of the points scored in these educational institutions are the results of competitions in their specialization subjects. For example, students of Chernivtsi Lyceum №1 of mathematical and economic specializations, took most of top places in academic competitions in mathematics, computer science, physics and astronomy, and students of T.G. Shevchenko Chernivtsi Gymnasium №1 - at competitions in German and English.

Quite high results were shown by students of the following educational institutions: Chernivtsi Gymnasium №4, Novoselytsia Secondary School №3 of I-III degrees - basic institution, Chernivtsi Gymnasium №5, basic institution Storozhynets Lyceum, Hlyboka Lyceum, Chernivtsi Gymnasium №2, Kelmentsi Lyceum basic institution, Chernivtsi Gymnasium № 7. In total, students of 193 general secondary education institutions took top places.

Another important intellectual competition is the all-Ukrainian competition-defense of research works of students-members of the Small Academy of Sciences of Ukraine. The main objectives of the competition are to identify and support gifted children, to involve intellectual and creatively gifted students in research and experimental work, to form an active civic position of students, to educate them in independence, perseverance, ability to form and defend their own opinion [10].

In 2020, 378 students took part in the second stage of the all-Ukrainian competition-defense of research works. The competition was held in 48 sections, which were grouped into 11 departments [13].

The largest number of works was presented in the department of Earth Sciences (88) and in the department of Literary Studies, Folklore and Art Studies (56) (Fig. 3). In general, in 2020, representatives of almost all administrative-territorial units of the oblast took part in the competition. The largest number of works was presented by students from Chernivtsi and Putyla rayon.

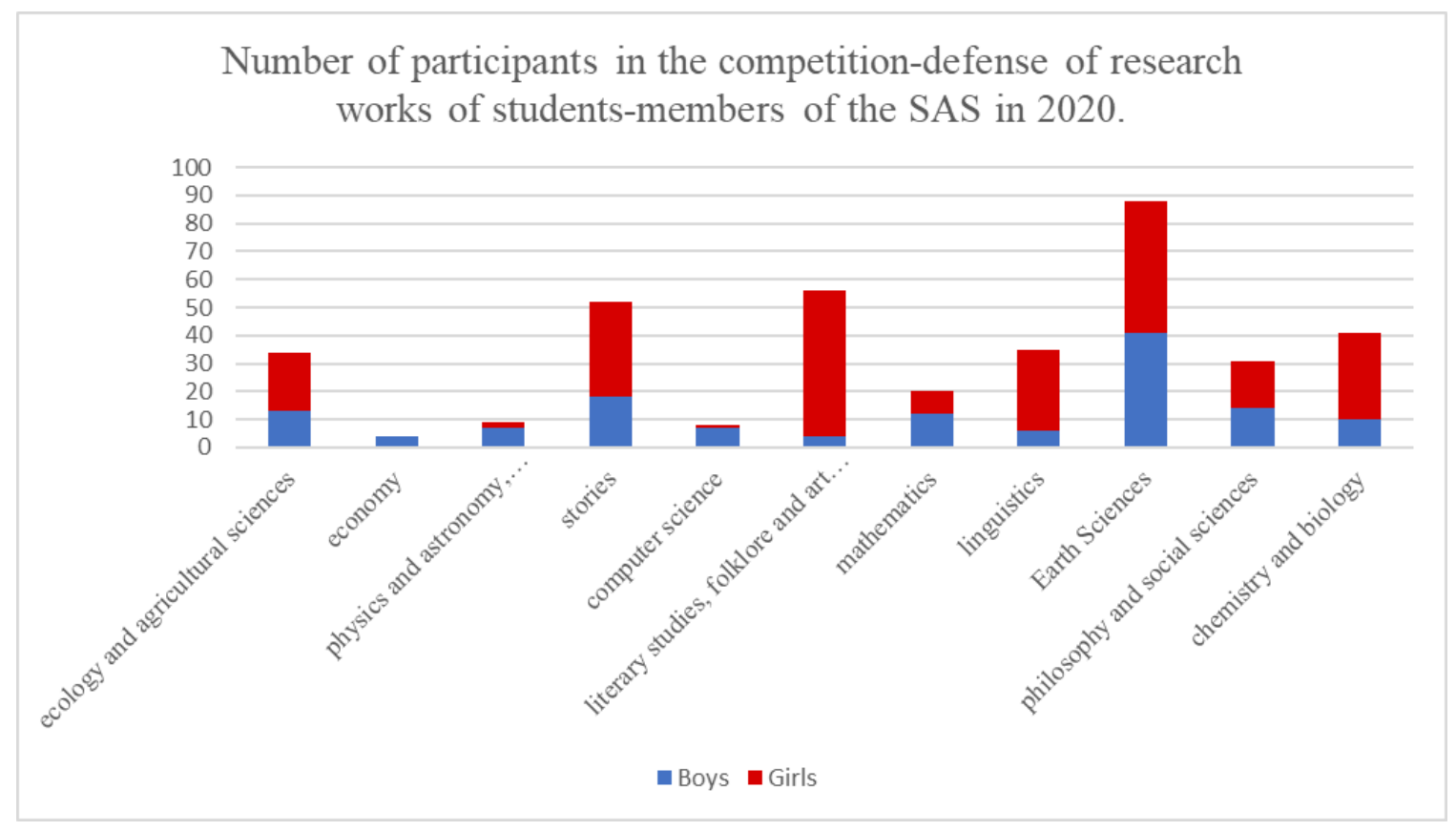

Fig. 3. Number of participants in the competition-defense of research works of students-members of the SAS in 2020

Top places at the II stage of the competition were taken by 187 participants of the competition, who study in 71 GSEI. Students of Chernivtsi Lyceum №1 (20), Putyla Gymnasium (18), Chernivtsi Lyceum №3 of medical specialization (18) and Chernivtsi Gymnasium №2 (16) received the highest number of points according to the results of the competition-defense of research works.

Based on the analysis, we propose to identify the following groups of administrative-territorial units of the oblast according to the level of students' results at the III stage of student competitions in basic disciplines:

I group (high level) - Chernivtsi. This type is characterized by a large number of GSEI, including institutions of a new type. Institutions with in-depth or special- ized study of individual subjects gained the largest share of points scored. It was from these competitions that they received the highest number of points;

Type II (intermediate level) - Storozhynets $\mathrm{AH}$, Novoselytsia AH, Kelmentsi rayon, Hlyboka AH, Vyzhnytsia rayon, Vyzhnytsia $\mathrm{AH}$, Kitsman $\mathrm{AH}$, Hlyboka rayon, Kitsman rayon, Zastavna rayon, Sokyriany rayon, Klishkivtsi $\mathrm{AH}$, Mamayivtsi $\mathrm{AH}$, Sokyriany $\mathrm{AH}$, Putyla rayon and Khotyn $\mathrm{AH}$. The main feature of this group is that most of the points scored were obtained by students of one or two educational institutions. Another feature here is top places in almost all competitions.

Type III (lower middle level) - Hertsa AH, Kon- 
iatyn $\mathrm{AH}$, Vashkivtsi $\mathrm{AH}$, Novoselytsia rayon, Karapchiv AH, Chudei AH, Yurkivtsi AH, Hertsa rayon, Novodnistrovsk, Nedoboivtsi AH, Chahor AH, Rukshyn $\mathrm{AH}$, Mamalyha AH, Khotyn rayon, Storozhynets rayon, Zastavna AH, Mahala AH, Vanchykivtsi AH and Nepolokivtsi AH. Characterized by a small number of ZSSO, including institutions of a new type.

Type IV (low level) - Terebleche AH, VelykyiKuchuriv AH, Vashkivtsi AH, Kostryzhivka AH, UstPutyla AH, Ostrytsia AH, Voloka AH, Krasnoilsk AH, Selyatyn AH, Stavchany AH, Vikno AH. They are characterized by a small number of ZSSOs and students. Most of the points were scored by students of one ZZSO or even one participant of the academic competition.

An important aspect in the study of intellectual potential is to identify factors influencing its development.

Territorial differences in the development of intellectual potential occur under the influence of economic, demographic, legal, environmental, natural and other factors. The following indicators correlate the most with the number of points scored by teams: the number of educational institutions in the rayon, AH or city (Pearson's correlation coefficient is 0.81 ), it was found that the greater the competition, the better the results in various intellectual competitions. Quite significant factors are the share of institutions of a new type (gymnasiums, lyceums, etc.) - in institutions of a new type in-depth study of individual subjects, while the study of other subjects is given less attention, which allows a better preparation for competitions in specific subjects; and the language of instruction - language is an important factor, especially in ethnocontact regions, because in some institutions education is conducted in the language of national minorities, and competitions are held in the state language.

At present, in Ukraine and the world, such a direction of geography as gender geography is gaining relevance. Gender geography is a socio-geographical science that studies the regional differences of gender relations in socio-geographical processes, regional features of gender identification and perception of gender roles in society [4].

673 boys and 1141 girls took part in the oblast stage of student competitions, which is $37.1 \%$ and $62.9 \%$. The share of girls in the structure of academic competition participants prevails in 14 out of 19 academic competitions (excluding the academic competition in labor training, because this academic competition is held separately for girls and boys).

The smallest share of boys (less than 10\%) among the participants was observed at the academic competition in Ukrainian language and literature, as well as in foreign literature.

Among the participants of the academic competition more boys than girls were observed in the academic competitions in Informatics (88.7\%), Information Technologies (67.9\%), Physics (61.2\%), Mathematics (53.5\%) and Astronomy (52.9).

287 boys and 502 girls took top places, which is $36.4 \%$ and $63.6 \%$ respectively (excluding the academic competition in labor).

The boys took top places among all participants at the academic competitions in Informatics (89.3\%), Information Technology (82.8\%), Mathematics (76.4\%), Astronomy (71.4\%) and Physics (55.3\%).

As for the second stage of the competition-defense of the SAS, the situation is a bit different compared to the academic competitions. A total of 378 students took part in the competition, of which 136 boys (36\%) and 242 girls (64\%).

The largest share of girls took part in the defense of scientific papers in the departments of literary studies, folklore and art history (93\%), linguistics (83\%) and in the department of chemistry and biology (76\%), while no girl took part in the defense of works in the economics section. Also a fairly low proportion of girls participated in the defense of scientific papers in the departments of computer science (8\%) and physics, astronomy and technical sciences (9\%). Approximate gender equality of participants is observed only in the Department of Earth Sciences.

A total of 116 girls (I - 21, II - 33, III - 62) and 71 (I -16 , II -21 , III - 34) boys or $62 \%$ and $38 \%$ respectively took top places.

In general, one can notice an interesting relationship between subjects and the gender relations of their participants. In intellectual competitions in subjects of philology and philosophy, girls show their knowledge better, while in subjects of physics and mathematics - boys.

Also, the components of intellectual potential include out-of-school educational institutions, which conduct a variety of educational, training and research work with young students. There are 45 out-of-school educational institutions (21 specialized, 9 complex and 15 children's and youth sports schools) in Chernivtsi region, in which 1421 clubs with 29,622 students are created. Among the areas of activity are dominated by sports, artistic, aesthetic and scientific and technical. It should be noted that there is only 1 research and experimental institution in the region - KOPNZ "Bukovynian Small Academy of Sciences for Student Youth" [18].

The highest level of formation of the intellectual potential of the region is vocational education institutions, higher education institutions and research institutions. In the Chernivtsi oblast, since 2005, there are 16 institutions of vocational (professional and technical) education, which currently have about 6 thousand people. During 2019, 2.9 thousand people graduated from vocational education institutions, which is the lowest figure since 2000. Higher education institutions of the region are represented by all levels of accreditation. As of the beginning of the 2019-2020 academic year, 6.8 thousand people studied in colleges, technical schools and colleges, which is almost 2 times less than in 2000. With regard to higher education institutions of III-IV level of accreditation, there are 3 such institutions in the region, which enroll 19.8 thousand students, of whom $76.8 \%$ studied full-time and $23.2 \%$ part-time. In 2019 , 2002 masters, 540 specialists, 3141 bachelors and 2502 junior specialists were trained. Also, at the end of 2019, postgraduate students were trained in 3 higher education institutions in the region and doctoral students were trained in 2 institutions. In 2019, 244 postgraduate students and 10 doctoral students were trained [17]. 


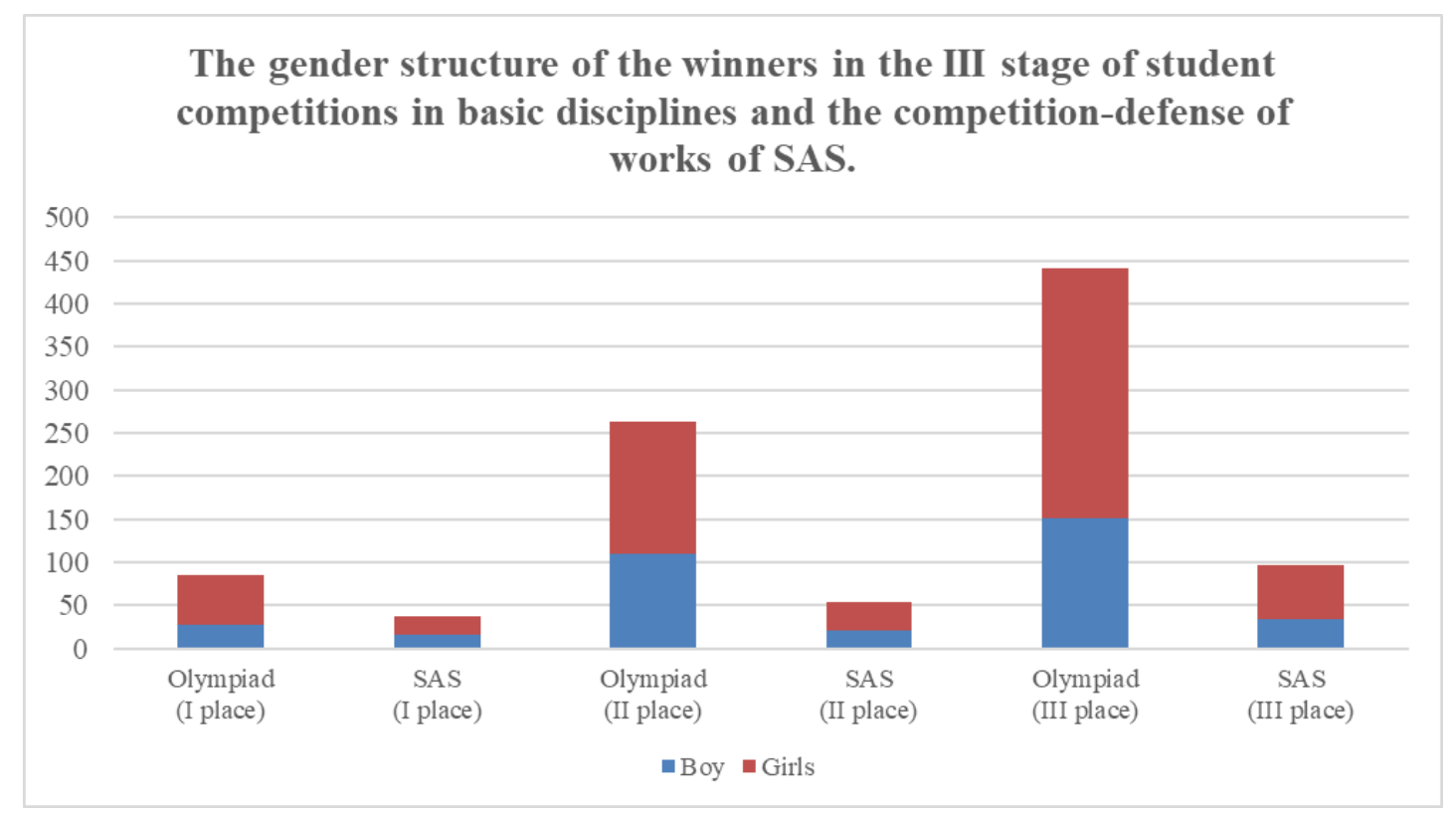

Fig. 4. The gender structure of the winners in the III stage of student competitions in basic disciplines and the competition-defense of works of SAS

One of the aspects of the structure of intellectual potential is functional-managerial - organizations and institutions that manage the system of intellectual potential and influence the development of educational and scientific objects, their interaction with the external environment and effective solution of tasks. They are formed at the level of oblasts, rayons and territorial communities, as well as within educational districts [7].

Conclusions. The study of the intellectual potential of the region from the standpoint of social geography is a new direction of scientific knowledge. Intellectual potential is a set of intellectual resources with their knowledge. The structure of intellectual potential is preschool education, complete general secondary education; extracurricular education, specialized education, professional (vocational) education, professional higher education and higher education.

In 2019, there were 372 preschool institutions in Chernivtsi oblast, which educated more than 31 thousand children, and the coverage of children by preschool institutions was $62 \%$. The next stage in the formation of the intellectual potential of the region is general secondary education. In the Chernivtsi oblast there are 402 ZZSO, in which studied 105.5 thousand students. Girls predominate in the gender structure of participants and winners of the academic competition and defense competition in most subjects. The number of boys predominates in competitions in computer science, mathematics, physics and astronomy.

There are also 16 vocational education institutions and 16 higher education institutions in the region. These institutions are mainly located in urban settlements, and most of them are in Chernivtsi.

As for the results of the third stage of student competitions in basic disciplines and competition-defense of scientific works of students of the Small Academy of Sciences, the best results are demonstrated by students of Chernivtsi, which can be justified by a significant number and, consequently, greater competition in the second stage of the competition, as well as a large number of institutions with in-depth or specialized study of individual subjects. Students of Storozhynets, Novoselytsia, and Hlyboka communities, as well as Kelmenets rayon, also show quite high results. Girls predominate in the gender structure of participants and winners of the academic competitions and defense competition in most subjects. The number of boys predominates in competitions in computer science, mathematics, physics and astronomy.

Thus, the intellectual potential is the basis of economic growth in the region, because in fact it further forms the intellectual capital.

\section{Список використаних джерел:}

1. Верхоглядова Н.I. Підходи до розуміння інтелектуального потенціалу / Н.I. Верхоглядова, О.А. Сидоров // Науковий вісник Ужгородського національного університету. Серія: Міжнародні економічні відносини та світове господарство. - 2018. - Вип. 18. - С. 77-80.

2. Гава Ю.В. Інтелектуальний капітал - шлях до економічного зростання України / Ю.В. Гава // Актуальні проблеми економіки. - 2006. - № 4. - С. 129-134.

3. Данилишин Б. Відтворення інтелектуального потенціалу у контексті розвитку знаннєвої економіки / Б. Данилишин, В. Куценко // Вісник НАН України. - 2004. - № 7. - С. 15-24.

4. Мезенцева Н. Гендер і географія в Україні: Монографія / Наталія Мезенцева, Ольга Кривець. - К.: НікаЦентр, 2013. - 194 с.

5. Наумчук О.М. Інтелектуальний потенціал регіону як об'єкт суспільно-географічного дослідження / О.М. Наумчук // Науковий вісник Чернівецького університету.-2013.-Випуск, 587-588. - С. $152-154$. 
6. Нич Т.В. Географія інтелектуального потенціалу / Т.В. Нич // Географія та туризм. - 2012. - Вип. 21. C. 161-167.

7. Нич Т.В. Суспільно-географічні аспекти дослідження формування інтелектуального потенціалу Хмельницької області: автореф. дис. на здобуття наук. ступеня канд. геогр. наук : спец. 11.00 .02 - економічна та соціальна географія / Нич Тетяна Василівна - Чернівці, 2016. - 24 с.

8. Паламарчук М.М. Економічна і соціальна географія України з основами теорії: Посібник / Паламарчук М.М., Паламарчук О.М. - К.: Знання, 1998 - 416 с.

9. Перерва П.Г. Інтелектуальний потенціал як економічна категорія / П.Г. Перерва, Л.С. Марчук // Вісник Національного технічного університету «Харківський політехнічний інститут» (економічні науки): зб. наук. пр. - Харків: НТУ «ХПІ», 2018. - № 15 (1291). - С. 53-63.

10. Про затвердження Положення про Всеукраїнські учнівські олімпіади, турніри, конкурси з навчальних предметів, конкурси-захисти науково-дослідницьких робіт, олімпіади зі спеціальних дисциплін та конкурси фахової майстерності: наказ М-ва освіти і науки, молоді та спорту України від 22 вересня 2011 р. № 1099 [Електронний ресурс] - Режим доступу до ресурсу: https://zakon.rada.gov.ua/laws/show/z1318-11

11. Про проведення I-II етапів Всеукраїнських учнівських олімпіад з навчальних предметів у 2019/2020 н.p. серед учнів 33СО, ПТО: наказ Департаменту освіти і науки Чернівецької ОДА від 12 вересня 2019 р. № 387 [Електронний ресурс] - Режим доступу до ресурсу: http://oblosvita.com/normatyvna_baza/nakaz/28285-nakazdon-vd-12092019-387.html

12. Про проведення III етапу Всеукраїнських учнівських олімпіад з навчальних предметів у 2019/2020 навчальному році: наказ Департаменту освіти і науки Чернівецької ОДА від 20 грудня 2019 р. [Електронний ресурс] - Режим доступу до ресурсу: http://oblosvita.com/uchnivski_olimpiady/28722-nakaz-departamentu-osvtinauki-vd-16122019-551.html

13. Про результати проведення II етапу Всеукраїнського конкурсу-захисту науково-дослідницьких робіт учнівчленів Буковинської Малої академії наук учнівської молоді, членів наукових товариств, об'єднань у 2019/2020 навчальному році: наказ Департаменту освіти і науки Чернівецької ОДА від 03 березня 2020 р. № 103 [Електронний ресурс]. - Режим доступу до pecypcy: http://oblosvita.com/normatyvna baza/29048nakaz-departamentu-osvti-nauki-vd-03-03-2020-103.html

14.Прошак В.В. Вплив освіти та науки на формування інтелектуального потенціалу України / В.В. Прошак // Формування ринкової економіки в Україні : наук. посібник - Львів : Інтереко, 1999. - 495-500 с.

15. Розумний М.М. Інтелектуальний потенціал України: проблема реалізації / М.М. Розумний // Наукові записки інституту журналістики. Інститут журналістики. К.: 2003. - Т. 12. Липень-вересень. - С. 90-93.

16. Сайт Буковинської малої академії наук учнівської молоді [Електронний ресурс]. - Режим доступу: http://chernivtsi.man.gov.ua/.

17. Статистичний щорічник Чернівецької області за 2019 рік / Головне управління статистики у Чернівецькій області; за ред. Т. Сарчинської. - Чернівці, 2020. - 480 с.

18. Чернівецька область. ІСУО [Електронний ресурс]. - Режим доступу: https://cv.isuo.org/zpo/authorities/zpolist/id/196

\section{References:}

1. Verkhohliadova, N. \& Sydorov, O. (2018). Pidkhody do rozuminnya intelektualnoho potentsialu [Approaches to understanding the intellectual potential]. Naukovyi visnyk Uzhhorodskoho natsionalnoho universytetu. Seriya: Mizhnarodni ekonomichni vidnosyny ta svitove hospodarstvo - Scientific Bulletin of Uzhgorod National University. Series: International Economic Relations and the World Economy, 18, 77-80 [in Ukrainian].

2. Gava, Yu.V. (2006). Intelektualnyi kapital - shliakh do ekonomichnoho zrostannia Ukrainy [Intellectual capital the way to economic growth of Ukraine]. Aktualni problemy ekonomiky - Actual problems of economy, 4, 129-134 [in Ukrainian].

3. Danylyshyn, B. \& Kutsenko V. (2004). Vidtvorennia intelektualnoho potentsialu u konteksti rozvytku znannievoi ekonomiky [Reproduction of intellectual potential in the context of knowledge economy development]. Visnyk NAN Ukrainy - Visnyk of NAS of Ukraine, 7, 15-24 [in Ukrainian].

4. Mezentseva, N. \& Kryvets, O. (2013). Hender i geografiya v Ukraini: Monografiya [Gender and geography in Ukraine: Monograph]. K.: Nika-Tsentr [in Ukrainian].

5. Naumchuk, O.M. (2013). Intelektualnyi potentsial regionu yak obyekt suspilno-geografichnoho doslidzhennya [Intellectual potential of the region as an object of socio-geographical research]. Naukovyi visnyk Chernivetskoho universytetu - Scientific Bulletin of Chernivtsi University, 587-588, 152-154 [in Ukrainian].

6. Nych, T.V. (2012). Geografiya intelektualnoho potentsialu [Geography of intellectual potential]. Geografiya ta turyzm - Geography and tourism, 21, 161-167 [in Ukrainian].

7. Nych, T.V. (2016). Suspilno-geografichni aspekty doslidzhennya formuvannya intelektualnoho potentsialu Khmelnytskoi oblasti [Socio-geographical aspects of the study of the formation of intellectual potential of the Khmelnytsky oblast]. Candidate's thesis. Chernivtsi [in Ukrainian].

8. Palamarchuk, M.M. \& Palamarchuk, O.M (1998). Ekonomichna i sotsialna geografiya Ukrainy z osnovamy teorii [Economic and social geography of Ukraine with the basics of theory]. K.: Znannya [in Ukrainian].

9. Pererva, P.H. \& Marchuk, L.S. (2018). Intelektualnyi potentsial yak ekonomichna katehoriia [Intellectual potential as an economic category]. Visnyk Natsionalnoho tekhnichnoho universytetu "Kharkivskyi politekhnichnyi instytut" 
(ekonomichni nauky) - Bulletin of the National Technical University "Kharkiv Polytechnic Institute" (economic sciences), 15 (1291), 53-63 [in Ukrainian].

10. Nakaz M-va osvity i nauky, molodi ta sportu Ukrainy Pro zatverdzhennia Polozhennia pro Vseukrainski uchnivski olimpiady, turniry, konkursy $\mathrm{z}$ navchalnykh predmetiv, konkursy-zakhysty naukovo-doslidnytskykh robit, olimpiady zi spetsialnykh dystsyplin ta konkursy fakhovoi maisternosti. № 1099 [Order of the Ministry of Education and Science, Youth and Sports of Ukraine On approval of the Regulations on all-Ukrainian student academic competitions, tournaments, competitions in academic subjects, competitions-defenses of research works, academic competitions in special disciplines and competitions of professional skills. №1099] (2011). Retrieved from https://zakon.rada.gov.ua/laws/show/z1318-11 [in Ukrainian].

11. Nakaz Departamentu osvity i nauky Chernivetskoi ODA Pro provedennia I-II etapiv Vseukrainskykh uchnivskykh olimpiad z navchalnykh predmetiv u 2019/2020 n.r. sered uchniv ZZSO, PTO [Order of the Department of Education and Science of Chernivtsi Oblast State Administration On holding the I-II stages of the all-Ukrainian student academic competitions in school subjects in 2019/2020 academic year. among students of ZZSO, VET]. № 387 (2019). Retrieved from http://oblosvita.com/normatyvna_baza/nakaz/28285-nakaz-don-vd-12092019387.html [in Ukrainian].

12. Nakaz Departamentu osvity i nauky Chernivetskoi ODA Pro provedennia III etapu Vseukrainskykh uchnivskykh olimpiad z navchalnykh predmetiv u 2019/2020 navchalnomu rotsi [Order of the Department of Education and Science of the Chernivtsi Oblast State Administration On conducting the III stage of the all-Ukrainian student academic competitions in school subjects in the 2019/2020 academic year]. (2019). Retrieved from http://oblosvita.com/uchnivski_olimpiady/28722-nakaz-departamentu-osvti-nauki-vd-16122019-551.htmll [in Ukrainian].

13. Nakaz Departamentu osvity i nauky Chernivetskoi ODA Pro rezultaty provedennia II etapu Vseukrainskoho konkursu-zakhystu naukovo-doslidnytskykh robit uchniv-chleniv Bukovynskoi Maloi akademii nauk uchnivskoi molodi, chleniv naukovykh tovarystv, obiednan u 2019/2020 navchalnomu rotsi [Order of the Department of Education and Science of the Chernivtsi Oblast State Administration On the results of the II stage of the allUkrainian competition-defense of research works of students-members of the Bukovynian Small Academy of Sciences of student youth, members of scientific societies, associations in the 2019/2020 academic year]. № 103 . (2020). Retrieved from http://oblosvita.com/normatyvna baza/29048-nakaz-departamentu-osvti-nauki-vd-03-032020-103.html [in Ukrainian].

14. Proshak, V.V. (1999). Vplyv osvity ta nauky na formuvannia intelektualnoho potentsialu Ukrainy [Influence of education and science on the formation of intellectual potential of Ukraine]. Formuvannia rynkovoi ekonomiky $v$ Ukraini - Formation of market economy in Ukraine, 5, 495-500 [in Ukrainian].

15. Rozumnyi, M.M. (2003). Intelektualnyi potentsial Ukrainy: problema realizatsii [Intellectual potential of Ukraine: the problem of realization]. Naukovi zapysky instytutu zhurnalistyky - Scientific Notes of the Institute of Journalism, 12, 90-93 [in Ukrainian].

16. Sait Bukovynskoi maloi akademii nauk uchnivskoi molodi [Site of Bukovynian small academy of sciences of student youth] (2020). Retrieved from http://chernivtsi.man.gov.ua/ [in Ukrainian].

17. Sarchynskoi, T. (Eds.). (2020) Statystychnyi shchorichnyk Chernivetskoi oblasti za 2019 rik [Statistical Yearbook of Chernivtsi oblast for 2019]. Chernivtsi: Holovne upravlinnia statystyky u Chernivetskii oblasti [in Ukrainian].

18. Chernivetska oblast. ISUO [Chernivtsi region. ISUO] (2020). Retrieved from https://cv.isuo.org/zpo/authorities/zpo-list/id/196 [in Ukrainian].

Надійшла до редколегї 07.11.2020 р.

\section{Про автора:}

Юрій Білоус - аспірант кафедри географії України та регіоналістики, Чернівецький національний університет імені Юрія Федьковича, вул. М. Коцюбинського 2, корп. 4, м. Чернівці, 58012, Україна, bilous_jura@ukr.net, https://orcid.org/0000-0001-8539-275X

\section{Об авторе:}

Юрий Билоус - аспирант кафедры географии Украины и регионалистики, Черновицкий национальный университет имени Юрия Федьковича, ул. М. Коцюбинского, 2, корп. 4, г. Черновцы, 58012, Украина, bilous_jura@ukr.net, https://orcid.org/0000-0001-8539-275X 